\title{
ADVANTAGES OF UTILIZING MICROWAVE IN SOFT LEATHER DRYING
}

\author{
Jinwei ZHANG ${ }^{1,2}$, Changlong ZHANG ${ }^{1}$, Jiacheng WU $^{1,2}$, Wuyong CHEN $^{1,2}$ \\ ${ }^{1}$ National Engineering Laboratory for Clean Technology of Leather Manufacture, Chengdu, 610065, China \\ ${ }^{2}$ Key Laboratory for Leather Chemistry and Engineering of the Education Ministry, Chengdu, 610065, China
}

Received: 24.11 .2016

Accepted: 22.02.2017

https://doi.org/10.24264/Ifj.17.2.1

\section{ADVANTAGES OF UTILIZING MICROWAVE IN SOFT LEATHER DRYING}

\begin{abstract}
The leather was dried by microwave and compared with the leather dried by oven in mechanical properties, softness, shrinkage temperature, microstructure as well as uniformities of chrome tanning agent, fatliquoring agent and dyestuff as new method for soft leather drying to keep and improve its softness and comprehensive properties. The results indicated that microwave drying would not damage leather collagen structure. Meanwhile, as microwave drying was even and would promote the combinations of collagen with other chemicals, the softness and mechanical properties of microwave dried leather were improved, in addition, the shrinkage temperature and uniformities of chrome tanning agent, fatliquoring agent and dyestuff were also promoted. Moreover, much more orderly and porous arrangement but less adhesion in collagen matrix of microwave dried leather were observed. These phenomena illustrated microwave dried leather could meet the high quality demands of leather better in softness and uniformity. To sum up, microwave has many advantages in drying soft leather products. KEY WORDS: microwave, garment leather, dry process, softness, uniformity
\end{abstract}

\section{AVANTAJELE UTILIZĂRII MICROUNDELOR LA USCAREA PIEILOR MOI}

REZUMAT. Pielea a fost uscată în cuptorul cu microunde şi comparată cu pielea uscată în etuvă în privinţa proprietăţilor mecanice, moliciunii, temperaturii de contracţie, microstructurii, precum şi uniformităţii agentului tanant, agentului de ungere şi colorantului ca o nouă metodă pentru uscarea pieilor moi în vederea menţinerii şi îmbunătăţirii moliciunii şi proprietăţilor acestora. Rezultatele au arătat că uscarea cu microunde nu deteriorează structura colagenului din piele. În acelaşi timp, întrucât uscarea cu microunde este uniformă şi favorizează combinarea colagenului cu alte substanţe chimice, s-au îmbunătăţit moliciunea şi proprietăţile mecanice ale pieii uscate la microunde; în plus, s-au îmbunătăţit şi temperatura de contracţie, uniformitatea agentului de tăbăcire în crom, a agentului de ungere şi a colorantului. Mai mult decât atât, s-a observat o configuraţie mult mai ordonată şi mai poroasă, dar şi o mai mică aderenţă a fibrelor în matricea de colagen la pielea uscată la microunde. Aceste fenomene au ilustrat faptul că pielea uscată la microunde ar putea satisface cerinţele de înaltă calitate ale pieii cu proprietăți de moliciune şi uniformitate mai bune. În concluzie, microundele au multe avantaje în ceea ce priveşte uscarea produselor din piei moi.

CUVINTE CHEIE: microunde, piele pentru îmbrăcăminte, proces de uscare, moliciune, uniformitate

\section{LES AVANTAGES DE L'UTILISATION DE MICRO-ONDES DANS LE SÉCHAGE DU CUIR SOUPLE}

RÉSUMÉ. Le cuir a été séché par micro-ondes et comparé au cuir séché en étuve en ce qui concerne les propriétés mécaniques, la souplesse, la température de rétraction, la microstructure ainsi que l'uniformité de l'agent de tannage au chrome, de l'agent de graissage et du colorant, comme une nouvelle méthode de séchage du cuir souple pour maintenir et améliorer sa souplesse et ses propriétés. Les résultats indiquent que le séchage par micro-ondes ne détériore pas la structure du collagène dans le cuir. Dans le même temps, alors que le séchage par microondes est uniforme et favorise les combinaisons de collagène avec d'autres produits chimiques, la souplesse et les propriétés mécaniques du cuir séché par micro-ondes ont été améliorées ; en plus, la température de rétraction et l'uniformité de l'agent de tannage au chrome, de l'agent de graissage et du colorant ont été aussi améliorées. En outre, on a observé un arrangement beaucoup plus ordonné et poreux, mais aussi moins d'adhérence des fibres dans la matrice de collagène au cuir séché aux micro-ondes. Ces phénomènes ont illustré que le cuir séché aux micro-ondes peut répondre aux exigences élevées de cuir plus souple et avec une bonne uniformité. Pour résumer, le micro-ondes présentent de nombreux avantages dans le séchage des produits en cuir souple.

MOTS CLÉS: micro-ondes, cuir pour vêtement, procédé sec, souplesse, uniformité régions importantes.

\section{INTRODUCTION}

Drying is an important process in leather making in which tanning agents, dyestuffs and fatliquoring agents combine with collagen further and water is evaporated to fulfil the demands of final leather product, therefore drying has significant influence on leather chemical and mechanical properties. Hanging, toggling, pasting, vacuum and heat pump are common drying methods, and the basic principles of these methods are to remove moisture through convection, conduction and radiation [1]. Traditional leather drying is time and energy consuming due to poor conductivity of leather. Microwave is a fast, time and energy saving heat resources with the remarkable advantages of selective heating ability, so it has been used to dry leather and leather coat as an efficient power [2-5].

* Correspondence to: Wuyong CHEN, Key Laboratory of Leather Chemistry and Engineering of Ministry of Education, Sichuan University, Chengdu 610065, China, email: wuyong.chen@163.com 
Microwave dried leather had more uniform water distribution and better feeling, in addition, leather would not harden or shrink in the process, resulting in larger area yield and softer leather product $[6,7]$. Moreover, when fatliquored leather was subjected to microwave irradiation, no leather structure damaging but fine fat distribution were observed, in addition, the particle size and viscosity of fatliquoring agent emulsion was decreased at the same time [8]. These advantages of microwave drying are much more suitable for soft leathers like garment and glove which have particular requirements in softness and fine feeling. However, many studies were focused on general leather microwave drying rather than targeting on soft leather [912].

In the study, goat garment leather was dried by microwave and compared with oven dried leather in mechanical properties, softness, shrinkage temperature, microstructure as well as uniformities of chrome tanning agent, fatliquoring agent and dyestuff to illustrate advantages of microwave drying for soft leather product. It would provide a new method for soft leather drying to keep its softness and improve microwave utilization in leather making.

\section{MATERIALS AND METHODS}

\section{Materials}

The goat wet blue with thickness of $0.9 \mathrm{~mm}$ was prepared in the lab and subjected to retanning, neutralizing, dyeing and fatliquoring according to conventional garment leather making process to get wet crust. The chemicals used for leather manufacturing were commercial grade and for analysis were research grade.

\section{Leather Sampling and Drying Method}

The wet crust was divided into two pieces along the backbone after $12 \mathrm{~h}$ standing. The samples used for microwave drying were cut for $30 \times 30 \mathrm{~cm}$ from belly and back respectively, the leathers with the same sampling method at symmetric position were used for oven drying.

The weight of each sample before drying was recorded and the water content was $80 \%$ (based on the total weight). A MCR-3S microwave reactor (Xi'an Yuhui instrument Co. Ltd. China) was used for drying microwave dried leather (MDL) with 100W heating power, the leather sample was heated $2 \mathrm{~min}$ every $2 \mathrm{~min}$ to prevent high temperature at the beginning to damage the leather. The oven dried leather (ODL) was dried in a DHG-9070A drying oven (Shanghai Feiyue Experimental instrument Co. Ltd. China) at $45^{\circ} \mathrm{C}$. The drying was ceased when the water content reduced to $20 \%$. Then the MDL and ODL samples were placed into a temperature humidity chamber at $25^{\circ} \mathrm{C}$ and $65 \%$ relative humidity for $24 \mathrm{~h}$.

\section{Test Methods}

\section{Physical Properties Measurement}

Both MDL and ODL samples were conditioned according to standard method before mechanical properties testing [13]. The tensile and tear strength were tested by an Al-7000S tensile machine (GOTECH testing Machines Inc. China) following standard $[14,15]$, and the softness was tested by GJ9E1 measuring apparatus (GOTECH testing Machines Inc. China) [16].

\section{Shrinkage Temperature (Ts) Measurement}

The shrinkage temperature was tested by MSW-YD4 Shrinkage Temperature Tester (China) with $75 \%$ glycerine bath. Each value was an average of two samples which were parallel and perpendicular to the backbone. Before testing, the samples were soaked in water for $2 \mathrm{~h}$ for rewetting.

\section{Chrome Content and Chrome Uniformity Measurement}

The samples were split into 3 uniform layers (about $0.3 \mathrm{~mm}$ ) and cut into about $1 \times 1 \mathrm{~mm}$ fragments, then dried in $102 \pm 2^{\circ} \mathrm{C}$ for $6 \mathrm{~h}$ to constant weight. Each sample (about $0.150 \mathrm{~g}$ ) was digested in a flask with $10 \mathrm{~mL} \mathrm{HNO}_{3}$ and $5 \mathrm{~mL} \mathrm{H}_{2} \mathrm{O}_{2}$ for $30 \mathrm{~min}$ at heating condition. After cooling down, the digested solution was dissolved in volumetric flask $(100 \mathrm{~mL})$. The total chromium content in digestion solution was determined by Optima 2100DV Inductively Coupled Plasma Atomic Emission Spectroscopy (Perkin Elmer, America) following the manufacturer's direction and $\mathrm{Cr}_{2} \mathrm{O}_{3}$ content in leather was calculated. Each value was an average of two tests. The uniformity of chrome distribution was calculated as formula 1 . 


$$
\text { chrome uniformity }(\%)=\frac{2 \times \mathrm{Cr}_{2} \mathrm{O}_{3} \text { in middle layer }}{\mathrm{Cr}_{2} \mathrm{O}_{3} \text { in grain layer }+\mathrm{Cr}_{2} \mathrm{O}_{3} \text { in flesh layer }} \times 100 \%
$$

Fat Content and Fat Uniformity Measurement

The samples were split into 3 uniform layers (about $0.3 \mathrm{~mm}$ ) and cut into about $1 \times 1 \mathrm{~mm}$ fragments. After drying in $102 \pm 2^{\circ} \mathrm{C}$ for $6 \mathrm{~h}$ to constant weight, fat content was determined by extraction with dichloromethane [17]. The uniformity of fat distribution was calculated as formula 2 .

\section{fat uniformity $(\%)=\frac{2 \times \text { fat in middle layer }}{\text { fat in grain layer }+ \text { fat in flesh layer }} \times 100 \%$}

\section{Dyestuff Distribution Measurement}

The leather were split into 3 uniform layers (about $0.3 \mathrm{~mm}$ ), and the colour difference between each layers and samples were determined to use X-Rite 8200 chroma colour difference meter (X-rite Company, America).

\section{Atomic Force Microscope (AFM) Measurement}

A SPM-9600 atomic force microscope (SHIMADZU, Japan) was exploited to observe the microstructure of the collagen fibres in leathers. The AFM images were obtained in ambient conditions at room $20^{\circ} \mathrm{C}$ with $65 \%$ relative humidity. The other testing conditions were as follows: NSG 11 probe with observing size as $0.25 \mu \mathrm{m}$.

\section{Scanning Electron Microscope (SEM) Measurement}

A JSM-5900LV scanning electron microscope (Japan Electronic Co. Ltd., Japan) was used for the analysis. The micrographs for the cross sections of leathers were obtained by operating the SEM at low vacuum (10-4Pa) with an accelerating voltage of $20 \mathrm{kV}$ at 1000 magnification levels.

\section{RESULTS AND DISCUSSIONS}

\section{Influence of Microwave Drying on Leather Mechanical Properties and Softness}

As shown in Table 1, the tensile strength, tear strength and softness of MDL are slightly better than $\mathrm{ODL}$, indicating leather mechanical properties and softness improved by microwave. Since water could absorb microwave more intensely than leather, leather drying rate under microwave slows down at the end of drying as leather moisture reduces obviously [7]. In addition, there is no temperature gradient in microwave heating, making uniform water evaporation at inner and surface of leather. However, drying rate and temperature of leather would not decrease and the surface would be over-dried in conventional because the drying is outside-in [10]. These characteristics of microwave drying prevent collagen fibre adhesion and stress concentration to improve leather mechanical properties and softness. Since garment leather will be used to make cloth, the improvement in mechanical properties and softness of garment leather is very important to keep flexibility but enhance strength.

Table 1: The mechanical properties and softness of ODL and MDL

\begin{tabular}{|c|c|c|c|c|c|c|}
\hline \multirow{2}{*}{ Sample } & \multicolumn{2}{|c|}{ Tensile strength: MPa } & \multicolumn{2}{|c|}{ Tear strength: $\mathrm{N} / \mathrm{mm}$} & \multicolumn{2}{|c|}{ Softness: mm } \\
\hline & Back & Belly & Back & Belly & Back & Belly \\
\hline MDL & 25.65 & 21.50 & 56.52 & 38.64 & 6.69 & 8.91 \\
\hline ODL & 23.10 & 20.10 & 55.13 & 36.51 & 6.23 & 8.30 \\
\hline
\end{tabular}




\section{Influence of Microwave Drying on Leather Shrinkage Temperature}

Table 2 demonstrated the Ts of MDL back and belly are $1.9^{\circ} \mathrm{C}$ and $0.9^{\circ} \mathrm{C}$ higher than ODL respectively, indicating MDL having better hydrothermal stability and better crosslink between collagen and tanning agents. Wang et al. [18] found microwave could increase chrome tanned leather shrinkage temperature further. As a consequence, chrome tanning agent crosslinks collagen in one step when leather subjected to microwave in drying and higher Ts is obtained just as in microwave assisting chrome tanning process.

Table 2: The shrinkage temperature of ODL and MDL

\begin{tabular}{ccc}
\hline Sample & Back Ts: ${ }^{\circ} \mathrm{C}$ & Belly Ts: ${ }^{\circ} \mathrm{C}$ \\
\hline MDL & 116.0 & 114.4 \\
ODL & 114.1 & 113.5 \\
\hline
\end{tabular}

\section{Influence of Microwave Drying on Chrome Migration}

The chrome uniformity of MDL samples are much more even than ODLs, especially the back is $24.28 \%$ higher than the control (shown in Table 3). High chrome uniformity represents low difference of chrome content between inner and surface of leather. As MDL has higher shrinkage temperature, the combination of chromium with collagen in MDL is more stable, leading free and weak combined chromium decreasing to avoid chromium migration in microwave drying. Furthermore, it might be inferred that other tanning agents could combine with collagen firmly as well. More uniform tanning agent distribution benefits for even cross-linkage all over the leather cross section to prevent stress concentration, in addition, it also has positive effect on improving leather mechanical properties and softness.

Table 3: Chrome uniformity of ODL and MDL

\begin{tabular}{ccc}
\hline \multirow{2}{*}{ Sample } & \multicolumn{2}{c}{ Chrome uniformity: \% } \\
& Back & Belly \\
\hline MDL & 80.60 & 85.18 \\
ODL & 56.32 & 82.31 \\
\hline
\end{tabular}

\section{Influence of Microwave Drying on Fat Migration}

Table 4 indicates the microwave drying could obtain better fat uniformity leather. Prior study had verified that microwave could reduce the viscosity and particle size of fatliquoring agent to increase the permeability [8], leading fat well distributed in microwave drying. As fatliquoring agent uniform existed in leather, it could lubricate fibres sufficiently and evenly to get better softness and improve mechanical properties of leather.

Table 4: Fat uniformity of ODL and MDL

\begin{tabular}{ccc}
\hline & \multicolumn{2}{c}{ Fat uniformity: \% } \\
Sample & Back & Belly \\
\hline MDL & 63.04 & 82.32 \\
ODL & 39.75 & 64.61 \\
\hline
\end{tabular}

Influence of Microwave Drying on Colour

The $L$ value represents lightness, $L=0$ yields black and $L=100$ yields white, so larger $L$ value means whiter colour and less dye stuff on the section. Table 5 shows the $L$ value of ODL middle layer is lower than MDL middle but the grain and flesh layers are higher than MDLs, demonstrating that there is more dyestuff in centre while less on the surface for ODL compared with MDL. As microwave could fix dyestuff further [19], it is difficult to migrate to surface in microwave drying.

Table 5: The lightness (L value) of each layer

\begin{tabular}{ccc}
\hline Layer & ODL & MDL \\
\hline Grain & 29.3 & 27.8 \\
Middle & 53.8 & 57.1 \\
Flesh & 31.2 & 25.6 \\
\hline
\end{tabular}

\section{Influence of Microwave Drying on Leather Microstructure}

The microstructure of the collagen fibres demonstrates in Fig. 1. The collagen fibres have characteristic axial D-periodic cross-striated fibril, which proves that the microstructure of collagen is not damaged during microwave drying. The surface of collagen fibre is not smooth according to the AFM images especially 
displayed in Figure 4A, and there is some stacking of leather chemicals which should be speculated as tanning agents, fatliquoring agents and dyestuffs. These phenomena demonstrate that microwave will not damage collagen structure but could promote combination of chemicals with collagen.
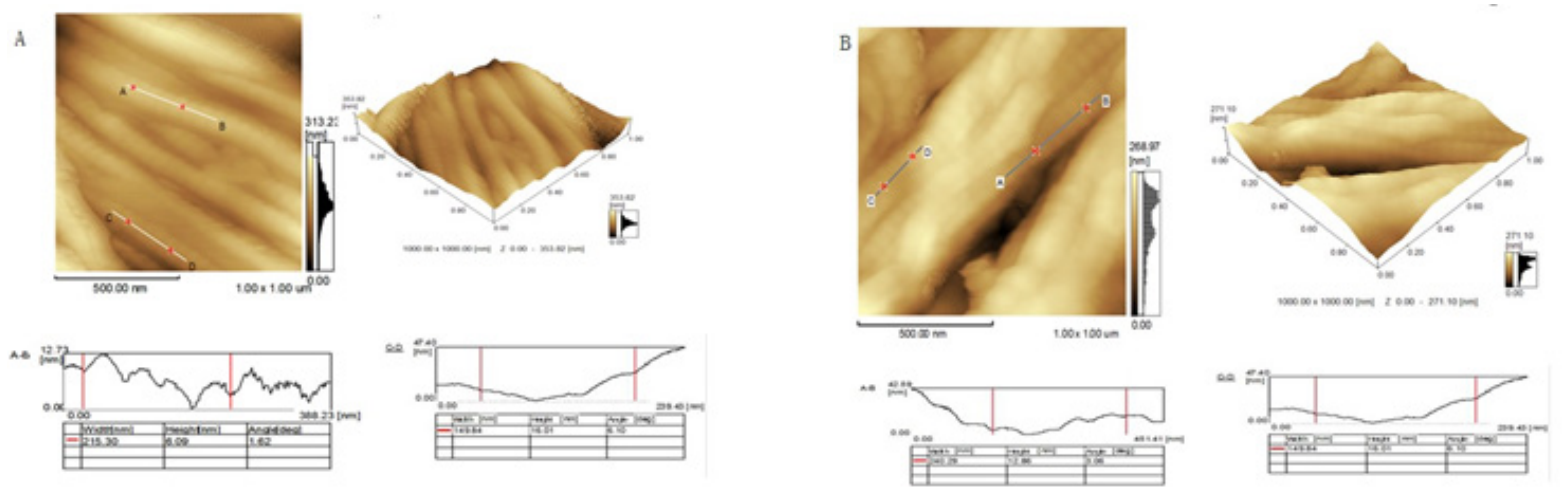

Figure 1. AFM images of MDL and ODL back ( $A: M D L, B: O D L)$
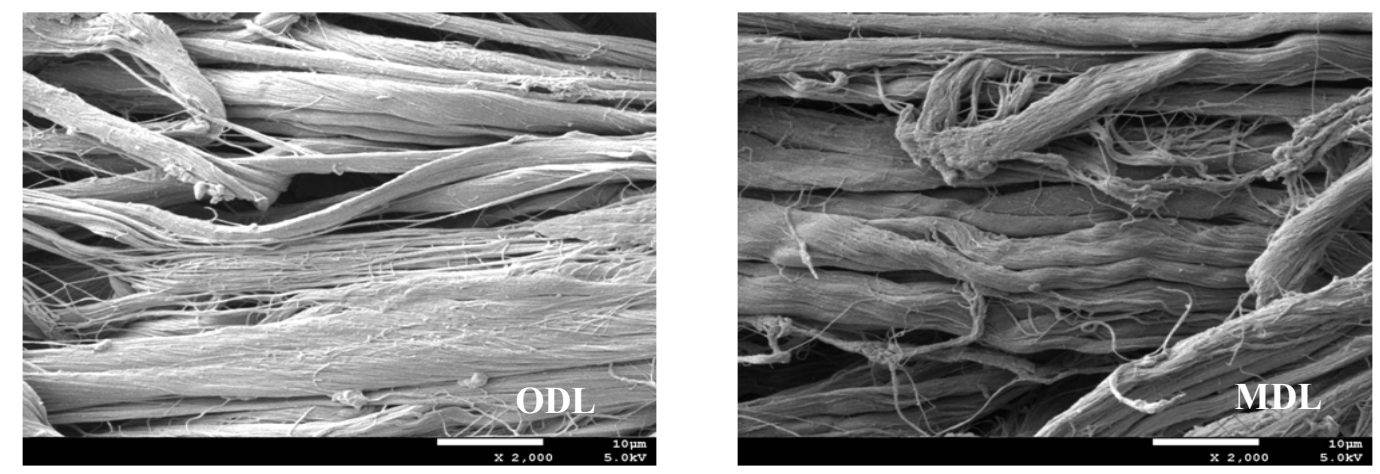

Figure 2. SEM images of MDL and ODL back (A: MDL, B: ODL)

According to Fig. 2, there is no significant difference between ODL and MDL in collagen weaving condition, but collagen fibre of MDL has a slight improvement in porosity and orderliness while adhesion between fibres decreases. It demonstrates microwave could not damage leather matrix too. In addition, because of more porosity but less fibre adhesion, higher area yield and better softness of garment leather are obtained compared with conventional drying.

\section{CONCLUSIONS}

Microwave drying would not damage leather collagen structure. Meanwhile, microwave dried leather has better mechanical properties and softness together with higher shrinkage temperature compared with oven drying; moreover, microwave could improve chrome, dyestuff and fat uniformity and make collagen fibre matrix arrange porously and orderly. These characteristics of microwave drying could not only keep the softness but also improve leather mechanical properties, and leather is more uniform all over the piece. To sum up, microwave has many advantages for drying soft leather products like garment and glove.

\section{Acknowledgements}

The authors wish to thank the financial support of National Natural Science Foundation of China (No. 21576171).

\section{REFERENCES}

1. Shan, Z.H., Leather Making Chemistry and Technology (Volume two), Science Press, Beijing, 2005.

2. Gilet, J., Drying without Heat, J Am Leather Chem Assoc, 1987, 82, 61-64. 
3. Komanowsky, M., Drying of Leather with Microwaves, J Am Leather Chem Assoc, 1990, 85, 131-141.

4. Zhang, C.L., Teng, B., Chen. W.Y., Effect of Microwave Drying on Properties of Leather Coating, Leather Science and Engineering, 2013, 35, 12-14

5. Zhang, J.W., Zhang, C.L., Chen, W.Y., Influence of Microwave Drying on Leather Finishing Film Forming Agent, Leather Science and Engineering, 2016, 26, 5-8.

6. Monzó-Cabrera, J., Catalá-Civera, J.M., DíazMorcillo, A., Sánchez-Hernández, D., PlazaGonzález, P.J., De los Reyes, E., A Three-Stage Microwave-Assisted Drying Model Based on the Dielectric Properties of Laminar Materials: Theoretical Development and Validation, Microw Opt Techn Let, 2002, 32, 465-469.

7. Monzó-Cabrera, J., Catalá-Civera, J.M., PlazaGonzález, P., Sánchez-Hernández, D., A Model for Microwave-Assisted Drying of Leather: Development and Validation, J Microw Power Electromagn Energy, 2004, 39, 53-64.

8. Gong, Y., Zhang, T., Chen, W.Y., Behavior of Fatliquored Leather in a Microwave Field, J Am Leather Chem Assoc, 2012, 107, 60-67.

9. Bajza, Z., The Influence of Fatliquor Concentration on Microwave Drying Kinetics, J Soc Leath Tech Chem, 1997, 81, 227-230.

10. Monzó-Cabrera, J., Díaz-Morcillo, A., CataláCivera, J.M., De los Reyes, E., Heat Flux and Heat Generation Characterization in a WetLaminar Body in Microwave-Assisted Drying: An Application to Microwave Drying of Leather, Int Commun Heat Mass, 2000, 27, 1101-1110.

11. Monzó-Cabrera, J., Díaz-Morcillo, A., CataláCivera, J.M., De los Reyes, E., Effect of
Dielectric Properties on Moisture Leveling in Microwave-Assisted Drying of Laminar Materials, Microw Opt Techn Let, 2001, 30, 165-168.

12. Monzó-Cabrera, J., Díaz-Morcillo, A., CataláCivera, J.M., De los Reyes, E., Kinetics of Combined Microwave and Hot Air Drying of Leather, J Soc Leath Tech Chem, 2000, 84, 3844.

13. IUP 3, Conditioning, I Soc Leath Tech Chem, 1998, 82, 199.

14. IUP 6, Measurement of Tensile Strength and Percentage of Elongation, J Soc Leath Tech Chem, 2000, 84, 317-321.

15. IUP 8, Measurement of Tear Load-Double Edge Load, J Soc Leath Tech Chem, 2000, 84, 327-329.

16. IUP 36, Measurement of Leather Softness, $J$ Soc Leath Tech Chem, 2001, 85, 458-460.

17. SLC-4, Determination of Substances (Fats and other Solubles) Soluble in Dichloromethane, $J$ Soc Leath Tech Chem, 1996, 80, 111-113.

18. Wang, H., Chen, W.Y., Gong, Y., Sun, H.B., Based on the Studies of Chrome Tanning Chemistry with Microwave, Leather Science and Engineering, 2011, 21, 10-14.

19. Gong, Y., Cheng, K., Zhang, T., Chen, W., Automated Clean Leather Dyeing Assisted by Wringing, Ultrasound and Microwave, J Am Leather Chem Assoc, 2011, 106, 127-132.

(C) 2017 by the author(s). Published by INCDTPICPI, Bucharest, RO. This is an open access article distributed under the terms and conditions of the Creative Commons Attribution license (http://creativecommons.org/licenses/by/4.0/). 